\title{
ANALISIS SISTEM PENGENDALIAN INTERN PERSEDIAAN BARANG DAGANG DAN PENERAPAN AKUNTANSI \\ (Studi Kasus pada CV. KARYA AGUNG LESTARI, Tulungagung)
}

\author{
Alfian Bahardiansyah, Riki Yulianto, Septika puspitasari \\ Alfiandian52@gmail.com \\ Ryulianto451@gmail.com \\ Septikapuspitasari55@gmail.com
}

\begin{abstract}
:
Signora branded household appliances products distributed by CV. Karya Agung Lestari which has various types of household appliances. Because there are many types of products and mobility in and out of goods, it is possible for various problems to occur which are feared to occur, such as physical differences between the inventory in the warehouse and the amount recorded in the inventory book, loss or theft of stock of goods, as a result, internal control and application of proper inventory accounting are needed. well so that there is no fraud in carrying out duties. The purpose of this study was to determine the effectiveness of internal control of merchandise inventory and its accounting application. Methods Data analysis carried out in this study was descriptive method. The results of the study can show that the overall internal control system for merchandise inventory at CV. Karya Agung Lestari can work well. The company's management has applied the concepts and principles of internal control, but on the other hand there are several procedures that do not reflect the concept of internal control. The company's management uses adequate internal control over the company's inventory as a whole, and the company establishes an internal auditor in order to investigate, supervise, and assess the effectiveness of the implementation of the elements of internal control of inventories that have been determined.
\end{abstract}

Keywords: inventory, internal control, PSAK No. 14

\section{Abstrak:}

Produk peralatan rumah tangga yang bermerk signora yang didistribusikan oleh CV. Karya Agung Lestari yang memilikiberbagai macamjenis peralatan rumah tangga. Karena sudah banyak jenis produk dan mobilitas keluar masuknya barang sehingga mungkinkan terjadinya berbagai masalah yang dikhawatirkan akan terjadi seperti halnya perbedaan fisik antar persediaan yang ada digudang dengan jumlah yang dicatat dibuku persediaan, kehilangan ataupun pencurian stock barang, akibatnya diperlukan pengendalin intern dan 
penerapan akuntansi persediaan yang baik agar tidak terjadi penyelewengan dalam menjalankan tugas.Tujuan penelitian ini adalah untuk mengetahui efektifitas pengendalian intern persediaan barang dagang dan penerapan akuntansinya Metode Analisis data yang dilakukan dalam penelitian ini adalah dengan metode deskriptif. Hasil penelitian dapat menunjukan secara keseluruhan sistem pengendalian intern persediaan barang dagang pada CV.Karya Agung Lestari dapat berjadan dengan baik. Manajemen perusahaan telah menerapkan konsep dan prinsip-prinsip pengendalian intern, namun disisi lain terdapat beberapa prosedur yang belum mencerminkan konsep pengendalian intern. Manajemen perusahaan menggunakan pengendalian intern yang memadai terhadap persediaan perusahaan secara keseluruhan, dan perusahaan membentuk auditor internal agar dapat menyelidiki, mengawasi, menilai efektivitas pelaksanaan unsur-unsur pengendalian intern persediaan barang yang sudah ditetapkan.

Kata kunci : persediaan, pengendalian intern, PSAK No. 14

\section{PENDAHULUAN}

\section{Latar belakang}

Persediaan merupakan unsur yang paling aktif dalam perusahaan dagang dan salah satu syarat pokok yang harus dipenuhi serta dimiliki oleh suatu perusahaan didalam aktifitas perdagangan karena dalam perdagangan yang diperdagangkan adalah persediaan tersebut.Maka semua aktivitas operasional perusahaan diprioritaskan pada usaha untuk melikuidasi persediaan tersebut menjadi kas beserta keuntungan yang diperoleh dari harga jual persediaan tersebut setelah dikurangi harga pokok penjualannya. Laporan neraca saldo perusahaan dagang persediaan adalah salah satu aktiva lancar yang mempunyai nilai investasi terbesar, sehingga dari hal tersebut diatas kita dapat mengetahui betapa pentingnya persediaan bagi perusahaan.

Persediaan sangat rentan terhadap kerusakan maupun pencurian. Kerusakan, pemasukan yang tidak benar, lalai untuk mencatat permintaan, barang yang dikeluarkan tidak sesuai pesanan, dan semua kemungkinan lainnya dapat menyebabkan catatan persediaan berbeda dengn persediaan yang sebenarnya ada digudang. Untuk itu diperlukan pengendalian intern persediaan yang bertujuan untuk melindungi harta perusahaan dan juga agar informasi mengenai persediaan lebih dapat dipercaya. Persediaan juga didefinisikan sebagai aktiva yang tersedia untuk dijual dalam kegiatan usaha normal dalam proses produksi atau yang dalam perjalanan dalam bentuk bahan atau perlengkapan (supplies) untuk digunakan dalam proses produksi atau pemberian jasa Pengendalian intern persediaan dapat dilakukan dengan melakukan tindakan pengamanan untuk mencegah terjadinya kerusakan, pencurian, maupun tindakan penyimpangan lainnya.

Penyusunan laporan keuangan persediaan merupakan hal yang sangat penting karena baik laporan Laba/Rugi maupun neraca tidak akan dapat disusun tanpa mengetahui nilai 
persediaan. Kesalahan pencatatan dan penilaian persediaan akan langsung berakibat kesalahan dalam laporan Laba/Rugi mupun Neraca. Oleh sebab itu perusahaan wajib mengikuti Standar Akuntansi Keuangan (SAK) yaitu Pernyataan Standar Akuntansi Keuangan (PSAK) No.14 membahas tentang akuntansi persediaan yng merupakan pedoman atas perlakuan akuntansi persediaan.

Tujuan penelitian ini adalah untuk mengetahui efektifitas pengendalian intern persediaan barang dagang yang diterapkan serta penerapan akuntansi persediaan barang dagang pada CV. KARYA AGUNG LESTARI

\section{LANDASAN TEORI}

\section{Konsep Sistem pengendalian Sistem}

Pada dasarnya kata sistem berasal dari kata yunani "sytema" yang berarti kesatuan, yakni keseluruhan dari bagian - bagian yang mempunyai hubungan satu sama lain. Untuk mendefinisikan sistem terdapat dua pendekatan, yaitu yang menekankan pada prosedurnya dan yang menekankan pada komponen atau elemennya. Pendekatan sistem yang menekankan pada prosedurnya mendefinisikan sistem sebagai suatu jaringan kerja dari prosedur-prosedur yang saling berhubungan, berkumpul bersama-sama untuk melakukan suatu kegiatan atau untuk menyelesaikan suatu sasaran yang tertentu. Prosedur adalah suatu uruturutan operasi klerikal (tulis menulis) biasanya melibatkan beberapa orang di dalam satu atau lebih departemen, yang diterapkan untuk menjamin penanganan yang seragam dari transaksitransaksi bisnis yang terjadi. Berbeda dengan sistem yang menekankan pada prosedurnya, sistem yang menekankan pada komponen atau elemennya mendefinisikan sistem sebagai kumpulan dari elemen-elemen yang berinteraksi untuk mencapai suatu tujuan tertentu. Pendekatan sistem yang merupakan kumpulan elemen- elemen atau komponen- komponen atau subsistem- subsistem merupakan definisi yang lebih luas. Pendekatan sistem yang menekankan pada komponen akan lebih di dalam mempelajari suatu sistem untuk tujuan analisis dan perancangan suatu sistem

\section{Menurut para ahli:}

Sistem menurut (Hall, 1956) adalah sekumpulan objek, yang mencakup hubungan diantara objek tersebut serta hubungan antara sifat yang mereka miliki.

Menurut (Ackoff, 1971) sistem terdiri dari empat elemen yaitu, objek, atribut, hubungan internal dan lingkungan. Objek dapat berupa benda fisik, abstrak, ataupun keduanya sekaligus, tergantung kepada sifat sistem tersebut. Atribut, yang menentukan kualitas atau sifat kepemilikan sistem dan objeknya. Hubunganinternal, keterkaitan objek objek didalam sistem. Contohnya Nomor Induk Mahasiswa berhubungan dengan jenis buku yang dipinjam. Lingkungan, berkaitan dengan dimana sistem itu ditempatkan, contohnya 
yaitu sistem perpustakaan yang dibuat digunakan di Jurusan Teknik Elektro.

Syarat - syarat sesuatu disebut sistem menurut (Jogiyanto, 2005) yaitu, sistem dibentuk untuk menyelesaikan masalah, elemen sistem mempunyai perencanaan yang sudah ditetapkan, adanya hubungan antara elemen sistem, proses lebih diutamakan dari pada element sistem.

Menurut (Kadir, 2002) bahwa "Sistem adalah sekumpulan elemen yang saling terkait atau terpadu yang dimaksudkan untuk mencapai suatu tujuan".

Menurut (Sutabri, 2012)bahwa "Sistem adalah suatu kumpulan atau himpunan dari suatu unsur, komponen, atau variabel yang terorganisasi, saling berinteraksi, saling tergantung satu sama lain dan terpadu".

Menurut (Fathansyah, 2015) bahwa "Sistem adalah sebuah tatanan (keterpaduan) yang terdiri atas sejumlah komponen fungsional (dengan satuan fungsi dan tugas khusus) yang saling berhubungan dan secara bersama-sama bertujuan untuk memenuhi suatu proses tertentu".

Dari beberapa pengertian di atas penulis dapat menyimpulkan bahwa sistem merupakan sekumpulan elemen, himpunan dari suatu unsur, komponen fungsional yang saling berhubungan dan berinteraksi satu sama lain untuk mencapai tujuan yang diharapkan.

Pengertian dan definisi sistem yang telah dijelaskan diatas berbeda - beda namun kita dapat mengambil beberapa bersamaan umum, yaitu sistem harus memliki elemen, lingkungan dan hubungan antar keduannya. Sistem Informasi Inventarisasi Buku Perpustakaan Jurusan Teknik Elektro Universitas NegeriSemarang nantinya akan terdiri dari elemen - elemen yang saling berhubungan sehingga akan menghasilkan sistem yang baik untuk memberikan informasi yang dibutuhkan.

\section{Konsep Pengendalian Intern}

Pengendalian intern merupakan kegiatan yang sangat penting sekali dalam pencapaian tujuan usaha. Demikian pula dunia usaha mempunyai perhatian yang makin meningkat terhadap pengendalian intern. Pengendalian intern adalah semua rencana organisasional , metode, dan pengukuran yang dipilih oleh suatu kegiatan usaha untuk mengamankan harta kekayaannya, mengecek keakuratan dan keandalan data akuntansi usaha tersebut, meningkatkan efisiensi operasional, dan mendukung dipatuhinya kebijakan manajerial yang telah ditetapkan (Anastasia, Diana. Setiawan, 2010) Sistem pengendalian intern terdiri atas kebijakan dan prosedur yang dirancang untuk memberikan kepastian yang layak bagi manajemen, bahwa perusahaan telah mencapai tujuan dan sasarannya (Herry, 2011)

Sistem informasi yang tidak memasukkan unsur pengendalian internal besar kemungkinannya system informasi tersebut tidak ada gunanya.Salah satu tujuan pengendalian internal adalah menghasilkan informasi keuangan yang andal dan dapat dipercaya. Jika sebuah system informasi yang tidak memiliki pengendalian misalnya, setelah seorang karyawan memasukkan transaksi penjualan, angka dalam aplikasi tersebut dapat diubah dengan mudah atau faktur yang terkait dengan penjualan dapat dihancurkan maka sekalipun menggunakan aplikasi akuntansi, maka pencurian kas yang diterima dari penjualan dapat dengan mudah terjadi (Anastasia, Diana. Setiawan, 2010) COSO menyebutkan bahwa 
pengendalian intern adalah suatu proses, melibatkan seluruh anggota organisasi, dan memiliki tiga tujuan utama, yaitu efektivitas, dan efisiensi operasi, mendorong kehandalan laporan keuangan, dan dipatuhinya hokum dan peraturan yang ada (Sanyoto., 2007)

\section{Pengendalian Intern}

Metode, prosedur, atau sistem yang dirancang oleh perusahaan untuk meningkatkan efisiensi, mengamankan harta, menjaga ketelitian data perakunan, menegakkan disiplin, dan meningkatkan ketaatan karyawan terhadap kebijakan perusahaan (internal control).

Otoritas Jasa Keuangan

Dalam teori akuntansi dan organisasi, pengendalian intern atau kontrol intern didefinisikan sebagai suatu proses, yang dipengaruhi oleh sumber daya manusia dan sistem teknologi informasi, yang dirancang untuk membantu organisasi mencapai suatu tujuan atau objektif tertentu. Pengendalian intern merupakan suatu cara untuk mengarahkan, mengawasi, dan mengukur sumber daya suatu organisasi.

Pengendalian intern adalah proses yang dilakukan atas amanat dari dewan direksi atau manajemen dalam suatu organisasi yang bertujuan untuk melindungi aset perusahaan, serta memastikan kepatuhan pada hukum dan peraturan yang berlaku. Pengendalian intern yang efektif dapat membantu perusahaan dalam mengarahkan kegiatan operasional perusahaan dan mencegah adanya kecurangan atau penyalahgunaan lainnya.

Pengertian Pengendalian Internal Menurut Ahli

Pengendalian internal sebelumnya sudah pernah dibahas oleh para ahli. Berikut adalah beberapa pengertian pengendalian internal.

(Horngren, 2009) Pengendalian internal adalah semua rencana dan tindakan dalam organisasional yang dirancang untuk mengamankan aktiva, mendorong karyawan agar mengikuti kebijakan perusahaan, memastikan catatan akuntansi yang tepat, dan meningkatkan efisiensi operasional.

(Dasaratha, V. Rama-Frederick, 2008) Pengendalian internal adalah suatu proses kebijakan perusahaan yang dipengaruhi oleh dewan direksi entitas, manajemen, dan personel-personel lainnya. Hal ini dibuat untuk memastikan kepastian terkait beberapa pencapaian meliputi, efektivitas dan efisiensi operasional, keakuratan laporan keuangan, dan ketaatan terhadap peraturan yang berlaku.

\section{Tujuan Pengendalian Intern}

1. Mencapai tujuan perusahaan yang sebelumnya sudah ditetapkan.

2. Menghasilkan laporan keuangan perusahaan yang dapat dipercaya.

3. Memastikan kegiatan perusahaan sejalan dengan hukum dan peraturan yang berlaku.

4. Mencegah kerugian atau pemborosan pengolahan sumber daya perusahaan. 
5. Menjaga keuangan perusahaan.

6. Mendorong efisiensi dalam kegiatan operasional perusahaan.

7. Memastikan dipatuhinya kebijakan atau peraturan yang sudah dibuat oleh manajemen perusahaan

\section{Komponen Pengendalian Intern}

Committee of Sponsoring Organizations of the Treatway Commission (COSO) mengidentifikasi lima komponen pengendalian intern yang meliputi:

\section{Lingkungan Pengendalian (Control Environment)}

Lingkungan pengendalian merupakan dasar dari semua komponen pengendalian intern lainnya yang membuat organisasi menjadi disiplin dan terstruktur. Lingkungan pengendalian mencakup suasana organisasi dan sikap manajemen serta karyawan terhadap pentingnya pengendalian yang ada dalam organisasi.

Ada beberapa faktor yang memengaruhi lingkungan pengendalian, yaitu:

- Integritas dan nilai kode etik perusahaan;

- Filosofi dan gaya operasional manajemen;

- Struktur organisasi;

- Praktik administrasi dan personal;

- Kebijakan operasional;

- Komitmen pada kompetensi.

Lingkungan pengendalian ini menjadi fondasi terhadap unsur-unsur yang membentuk pengendalian internal lainnya. Suatu organisasi jika tidak memiliki fondasi tentunya akan roboh karena tidak ada aturan-aturan yang berlaku dan integritas yang dimiliki suatu organisasi tersebut.

\section{Penilaian Risiko (Risk Assesment)}

Penilaian risiko adalah identifikasi analisis dan pengelolaan risiko suatu organisasi. Suatu risiko yang telah diidentifikasi dapat dianalisis sehingga dapat diperkirakan tindakan yang dapat meminimalisirnya.

\section{Prosedur Pengendalian (Control Activities)}

Prosedur pengendalian adalah kebijakan atau prosedur yang dibuat untuk memastikan tercapainya tujuan perusahaan dan mencegah 
terjadinya kecurangan.Dalam melakukan pengendalian internal tentunya ada prosedur-prosedur yang harus dilakukan terlebih dahulu. Ini bertujuan agar pengendalian internal tetap berjalan sesuai yang sudah direncanakan. Adanya prosedur ini juga sebagai pencegahan terhadap kecurangan dan kesalahan dalam aktivitas perusahaan.

Prosedur dalam pengendalian internal meliputi:

- Karyawan yang berpotensi;

- Rotasi kinerja dan kewajiban cuti;

- Ulasan kinerja;

- Pemisahan fungsi dan tanggung jawab;

- Perlindungan aset dan data akuntansi.

\section{Pengawasan (Monitoring)}

Pengawasan adalah proses untuk menilai kualitas kinerja pengendalian intern suatu organisasi. Pengawasan dilakukan untuk menemukan kekurangan serta meningkatkan efektivitas pengendalian intern.

\section{Informasi dan Komunikasi (Information and Communication)}

Informasi diperlukan dari pihak luar perusahaan. Manajemen dapat menggunakan informasi ini untuk menilai standar eksternal. Komunikasi melibatkan penyediaan suatu pemahaman yang jelas mengenai peran dan tanggung jawab individu berhubungan dengan pengendalian internal atas pelaporan keuangan.

\section{Jenis Pengendalian Internal}

Berdasarkan tujuan dari pengendalian internal maka jenis pengendalian internal ini dibagi menjadi dua yaitu, pengendalian internal akuntansi, dan pengendalian internal administrasi.

\section{Pengendalian Internal Akuntansi}

Yang dikendalikan dalam pengendalian internal akuntansi ini meliputi, keandalan data, persetujuan, pemisahan fungsi operasional, pencatatan, pengawasan, serta pengawasan aset perusahaan.

\section{Pengendalian Internal Administrasi}

Dalam pengendaliannya, internal administrasi mengurus beberapa hal meliputi, 
efisiensi usaha, analisis risiko, kebijakan direksi, manajemen sumber daya, dan pengendalian mutu.

Berdasarkan manfaatnya, jenis pengendalian internal juga dibagi menjadi tiga kelompok, yaitu.

\section{Pengendalian Preventif}

Pengendalian ini digunakan untuk mencegah kesalahan yang terjadi. Dalam hal ini secara otomatis akan dilakukan pengecekan yang dirancang untuk mencegah penyalahgunaan.

\section{Pengendalian Detektif}

Pengendalian ini digunakan untuk mendeteksi kesalahan-kesalahan yang terjadi dalam memasukkan data.

\section{Pengendalian Korektif}

Pengendalian ini digunakan untuk memberikan informasi kepada pihak manajemen untuk memperbaiki kesalahan yang terjadi. Pengendalian ini dirancang untuk mengoreksi kesalahan yang terdeteksi.

Berdasarkan cakupannya, jenis pengendalian internal juga dibagi lagi menjadi dua kelompok, yaitu.

\section{Pengendalian Umum}

Pengendalian ini digunakan untuk memproses semua aktivitas yang berhubungan dengan data di dalam komputer. Hal-hal yang diproses meliputi, pemisahan tanggung jawab dan pengolahan data.

\section{Pengendalian Aplikasi}

Pengendalian ini digunakan untuk mengawasi jalannya transaksi dan penggunaan program di aplikasi-aplikasi komputer. Pengendalian ini bertujuan untuk menjaga setiap transaksi harus selalu dicatat, mendapat otorisasi, diproses, dan dilaporkan dengan baik.

\section{Arti Penting Pengembangan Sistem}

(Rachmad Gesah Mukti prabowo, 2015) Pengembangan sistem (systems development) merupakan menyusun suatu sistem yang baru untuk menggantikan sistem yang lama secara keseluruhan atau memperbaikis istem yang telah ada. Sistem yang lama perlu diperbaiki atau 
diganti disebabkan karena beberapa hal, yaitu sebagai berikut ini:

1. Adanya permasalahan-permasalahan (problems) yang timbul di sistem yang lama.

2. Ketidakberesan dalam sistem yang lama menyebabkan sistem yang lama tidak dapat beroperasi sesuai dengan yang diharapkan.

3. Kecurangan-kecurangan disengaja yang menyebabkan tidak amannya harta kekayaan perusahaan dan kebenaran dari data menjadi kurang terjamin.

4. Kesalahan-kesalahan yang tidak disengaja yang juga dapat menyebabkan kebenaran dari data kurang terjamin.

5. Tidak efisiennya operasi.

6. Tidak ditaatinya kebijaksanaan manajemen yang telah ditetapkan.

\section{Perlakuan Akuntansi Persediaan Barang Dagang Menurut PSAK No. 14}

Teknik pengukuran biaya persediaan seperti metode biaya standar atau metode eceran, demi kemudahan dapat digunakan jika hasilnya mendekati biaya.Biaya standar memperhitungkan tingkat normal penggunaan bahan dan perlengkapan, tenaga kerja, efisiensi dan utilitas kapasitas. Biaya standar di review secara regular dan jika diperlukan di revisi sesuai regular dan jika diperlukan direvisi sesuai dengan kondisi terakhir. Metode eceran seringkali digunakan dalam industry eceran untuk menilai persediaan dalam jumlah besar item yang berubah dengan cepat, dan memiliki marjin yang sama dimana tidak praktis untuk menggunakan metode penetapan biaya lainnya. Biaya persediaan ditentukan dengan mengurangi nilai jual persediaan dengan persentase marjin bruto yang sesuai.Persentase tersebut digunakan dengan memerhatikan persediaan yang telah diturunkan nilainya dibawah harga jual normal.Persentasi rata-rata sering digunakan untuk setiap department eceran.

\section{Persediaan}

Persediaan adalah asset tersedia untuk dijual dalam kegiatan usaha biasa, dalam proses produksi untuk penjualan tersebut, atau dalam bentuk bahan atau perlengkapan untuk digunakan dalam proses produksi atau pemberian jasa. Persediaan adalah suatu aktiva yang meliputi barang-barang milik perusahaan dengan maksud untuk dijual dalam satu periode usaha yang normal, termasuk barang yang dalam pengerjaan /proses produksi menunggu masa penggunaannya pada proses produksi (Prasetyo, 2006)

Dalam sebuah perusahaan persediaan barang dagang merupakan milik perusahaan yang siap untuk dijual kepada para konsumen. Pada setiap tingkat perusahaan baik perusahaan kecil, menengah mauun besar, persediaan sangat penting bagi kelangsungan hidup perusahaan. Perusahaan harus dapat memperkirakan jumlah persediaan yang 
dimilikinya. Persediaan yang dimiliki oleh perusahaan tidak boleh terlalu banyak dan juga tidak boleh sedikit karena akan mempengaruhi biaya yang akan dikeluarkan untuk biaya tersebut. Adapun definisi persediaan barang dagang menurut para ahli adalah :

Pengertian persediaan menurut (Suharli, 2006) adalah barang yang dibeli untuk dijual lagi sebagai aktivitas utama perusahaan untuk memperoleh

Dari definisi tersebut dapat disimpulkan bahwa persediaan barang dagangan merupakan barang-barang yang disediakan dengan tujuan untuk dijual kembali kepada para konsumen dan digunakan untuk mencatat harga pokok barang dagang selama periode normal kegiatan perusahaan.

\section{Jenis-Jenis Persediaan}

Persediaan dapat diklasifikasikan menurut beberapa kategori, tergantung pada jenis kegiatan usaha perusahaan apakah perusahaan itu merupakan perusahaan dagang atau manufaktur. Menurut (Donald, 2002) persediaan dapat diklasifikasikan berdasarkan kegiatan usahanya yaitu sebagai berikut :

\section{Perusahaan Dagang}

Dalam perusahaan dagang, perusahaan hanya mengeal satu jenis persediaan yaitu barang dagangan yang siap untuk dijual.

2. Perusahaan Manufaktur Terdapat

3 jenis barang yaitu :

1. Persediaan bahan baku untuk diproduksi

Meliputi bahan baku yang diperoleh dari sumber daya alam ataupun beberpa jenis produk yang dibeli dar perusahaan lain

2. Persediaan barang dalam proses

Meliputi produk-produk yang telah dimasukkan ke dalam proses produksi, namaun belum selesai diolah.

3. Persediaan barang jadi

Meliputi produk olahan yang siap dijual kepada pelanggan.

\section{Metode Penilaian Persediaan}

Setelah perusahaan memilih sistem pencatatan yang dilakukan, kemudian ditentukan 
metode penelitian persediaan yang bertujuan untuk menelaah laporan keuangan, oleh karena itu pemilihan metode penilaian persediaan mempunyai arti penting dalam menelaah laporan keuangan. Terdapat 3 metode penilaian persediaan,yaitu

\section{Metode FIFO (First In First Out)}

Dengan metode ini maka harga pokok barang yang tersedia untuk dijual dihitung dengan cara barang yang pertama masuk (dibeli) akan dijual terlebih dahulu. Kekurangannya baru diambil dari barang yang masuk berikutnya.

\section{Metode LIFO (Last In First Out)}

Dengan metode ini maka harga pokok barang yang tersedia untuk dijual dihitung dengan cara barang yang terakhir masuk (dibeli) akan dijual terlebih dahulu. Kekurangannya baru diambil dari barang yang terakhir masuk berikutnya.

\section{Metode Rata-Rata (Average)}

Disebut metode rata-rata, karena dalam metode ini harga beli rata- rata persatuan harus dihitung setiap transaksi pembelian barang. Dengan demikian harga rata-rata persatuan akan berlaku sampai terjadi transaksi pembelian berikutnya.

\section{Sistem Pencatatan Persediaan}

Sistem pencatatan (inventory system) yng dilakukan untuk mencatat semua persediaan barang selama terjadi transaksi, sistem pencatatan tersebut dibagi menjadi 2 jenis pencatatan yaitu :

\section{Sistem Periodik (Periodic Method)}

Sistem periodik adalah sistem pencatatan yang biasanya digunakan di dalam akuntansi, dalam sistem ini semua jumlah nilai persediaan hanya akan diketahui pada akhir periode saja untuk menyiapkan pembuatan laporan keuangan. Menurut (Jusup, 2001) rekening persediaan tidak digunakan unutk mencatat pertambahan persediaan karena adanya transaksi pembelian, dan tidak digunakan untuk mencatat pengurangan persediaan karena adanya transaksi penjualan. Informasi mengenai persediaan yang ada pada suatu saat tertentu, tidak dapat diperoleh dari rekening persediaan, demikian pula harga pokok barang yang dijual tidak dapat diketahui untuk setiap transaksi penjualan yang terjadi. Untuk perhitungan harga pokok penjualan selama periode tertentu di hitung dengan menggunkan cara sebagai berikut ; 
HPP $=$ Persediaan Awal $+($ Pembelian $-[\{$ Retur + Potongan pembelian $\}+$ Biaya Angkut Pembelian]) -Persediaan Akhir Sistem Balans Permanen (Perpetual Method)

menurut (Jusup, 2001) pembelian barang dagangan dicatat dengan mendebet rekening persediaan sebesar harga perolehannya. Dalam sistem ini rekening pembelian tidak digunakan apabila terjadi penjualan barang dagangan, maka perusahaan membuat dua ayat jurnal. Jurnal yang pertama dibuat untuk mencatat penjualan barang dagangan sebesar harga jualnya, sedangkan jurnal yang kedua dibuat untuk mencatat harga pokokpenjualan dan pengurangan persediaan sebesar harga perolehannya.

\section{Konsep Persediaan}

\section{Metode Pencatatan Persediaan}

Metode pencatatan persediaan ada dua yaitu metode periodic dan metode perpectual.Metode periodic disebut juga metode fisik,dikatakan demikian karena pada akhir periode dihitung fisik barang untuk mengetahui persediaan akhir yang nantinya akan dibuat jurnal penyesuaian sedangkan metode perpectual disebut juga metode buku, karena setiap jenis persediaan mempunyai kartu persediaan.

2 Metode Penilaian Persediaan

a) Penilaian Persediaan Berdasarkan Harga Pokok

Penentauan harga pokok persediaan sangat bergantung dari metode penilaian yang dipakai yaitu : metode identifikasi khusus, masuk pertama keluar pertama (FIFO), masuk terakhir keluar pertama (LIFO), dan metode biaya rata-rata (weighted average).

b) Penilaian Persediaan Selain dari Harga Pokok

Dalam beberapa kasus, persediaan dapat dinilai selain dari harga pokok. (Warren Carl. S, 2005)mengatakan bahwa situasi macam itu timbul apabila biaya penggantian barang-barang persediaan lebih rendah dari biaya yng tercatat dan persediaan tidak dapat dijual pada harga jual normal karena cacat, usang,perubahan gaya, atau penyebab lainnya. 


\section{Penjualan}

Penjualan merupakan pembelian sesuatu (barang atau jasa) dari suatu pihak kepada pihak lainnya dengan mendapatkan ganti uang dari pihak tersebut. Penjualan juga merupakan suatu sumber pendapatan perusahaan, semakin besar penjualan maka semakin besar pula pendapatan yang diperoleh perusahaan.

Berdasarkan pengertian di atas, maka dapat disimpulkan bahwa penjualan adalah persetujuan kedua belah pihak antara penjual dan pembeli, dimana penjual menawarkan suatu produk dengan harapan pembeli dapat menyerahkan sejumlah uang sebagai alat ukur produk tersebut sebesar harga jual yang telah disepakati.

\section{Harga Pokok Penjualan (HPP)}

Pengertian harga pokok penjualan adalah total harga pokok penjualan barang selama periode tertentu, yang dihitung secara menjumlahkan harga pokok pembelian dari barangbarang yang dibeli dalam periode tersebut dengan harga pokok barang- barang yang ada pada awal periode tersebut, kemudian mengurangi hasilnya dengan harga pokok dari barangbarang yang tersisa pada akhir periode yang sama.

\section{METODE PENELITIAN}

\section{Jenis dan Sumber Data}

1. Jenis Data

Jenis data yang dikumpulkan dalam penelitian ini adalah data kualitatif yaitu serangkaian observasi dimana tiap observasi kemungkinannya tidak dapat dinyatakan dalam angkaangka (STIM, 2008) 
2. Sumber Data

a. Data primer, berupa data yang diperoleh langsung dari perusahaan melalui wawancara dengan staf bagian gudang, dan bagian penjualan dan karyawan yang terkait langsung dengan objek yang diteliti, dan kegiatan observasi yang kemudian akan diolah penulis.

b. Data sekunder, berupa data yang dikumpulkan melalui catatan dan dokumen resmi perusahaan dan data yang telah diolah seperti sejarah singkat perusahaan,struktur organisasi, laporan pembelian, persediaan dan laporan penjualan.

\section{Teknik dan Pengumpulan Data}

Teknik yang digunakan dalam mengumpulkan data adalah :

1. Teknik wawancara, yakni dengan melakukan Tanya jawab secara langsung dengan pihak-pihak terakait dengan objek penelitian.khususnya dengan bagian berhubungan dengan objek penelitian.

2. Teknik observasi, yakni dengan melakukan pengamatan terhadap aktivitas yang berhubungan dengan pengendalian intern dan penerapan akuntansi persediaan kepada perusahaan.

\section{Metode Analisis Data}

Metode Analisis data yang dilakukan dalam penelitian ini adalah dengan metode deskriptif. Metode deskriptif adalah metode analisis dengan terlebih dahulu mengumpulkan data yang ada kemudian diklarifikasi, dianalisis, selanjutnya diinterpretasikan sehingga dapat memberikan gambaran yang jelas mengenai keadaan yang diteliti.

\section{Teknik Analisis data}

1. Mengumpulkan data dan informasi tentnag persediaan berdasarkan hasil wawancara. 
2. Mempelajari dan mengkaji data dan informasi tentang persediaan.

3. Menguraikan sistem pengendalian intern dan mengaitkannya dengan persediaan, sesuai pustaka yang ada.

4. Mempelajari penerapan PSAK No. 14 sebagai pendukung analisis SPI sesuai dengan pustaka yang ada.

5. Menarik kesimpulan atas uraian dan penjelasan yang telah dilakukan.

\section{HASIL PENELITIAN DAN PEMBAHASAN}

\section{Hasil Penelitian}

\section{Gambaran Umum Objek Perusahaan}

Sejarah Singkat Perusahaan

CV. KARYA AGUNG LESTARI. CV. KARYA AGUNG LESTARI didirikan pada tanggal 8 Mei 2014. CV. KARYA AGUNG LESTARI adalah perusahaan nasional yang bergerak di bidang distributor alat-alat dapur atau alat keperluan dapur yang sudah mempunyai cabang di Tulingagung, malang, kediri.

Visi Perusahaan:

Menjadi Perusahaan distributor alat dapur yang mempunyai daya saing dan menjadi pemain alat kesehatan terkemuka didaerah dan diluar daerah

Misi

Perus

ahaan

:

1. Memenuhi kebutuhan masyrakat akan peralatan kesehatan yang mempunyai keunggulan kompetitif.

2. Mengembangkan kompetensi sumber daya manusia (karyawan) sehingga dapat berperan dalam pengembangan perusahaan.

3. Memberikan pelayanan kepada konsumen secara maksimal sehingga keberadaan perusahaan dapat bermanfaat bagi mayarakat umum dan semua pihak yang berhubungan dengan perusahaan. 
Jenis-jenis persediaan

Persediaan yang dimiliki oleh CV. KARYA AGUNG LESTAR jenis persediaan barang dagang yang dibeli dan dijual kembali jenis-jenis persediaan barang dagangyang dimiliki CV. KARYA AGUNG LESTARI menurut kondisinya: a). Persediaan baik digudang yatiu persediaan yang disimpan sementara digudang penyimpanan sebelum dijual.

b). Persediaan siap untuk dijual yaitu persediaan yang siap untuk dijual kepada pembeli atau pelanggan.

c). Persediaan rusak yaitu persediaan yang mutunya tidak sama seperti semula atau sudah habis masa kadaluarsanya yang dapt dijual dibawah harga pokok atau tidak dapat dijual atau dicadangkan dalam persediaan rusak.

Biaya-Biaya Persediaan

CV. KARYA AGUNG LESTAR seringkali menemukan persediaan rusak, maka perusahaan perlu melakukan retur pembelian.

Jurnal Retur

Pembelian

$\overline{\text { Hutang Dagang }}$ xxx

Persediaan $\quad \mathrm{xxx}$

Ketentuan mengenai barang yang diakui menjadi persediaan perusahaan adalah diakui jika sudah sampai dan diterima oleh bagian logistik yang diantar langsung oleh supplier atau pemasok. Mengenai pajak pertambahan nilai yang dibebankan perusahaan supplier kepada perusahaan, perusahaan membebankan kembali kepada pembeli dan langsung ditambahkan ke harga jual barang.Maka muncul perkiraan PPN masuk dan PPN keluar dalam perkiraan laba rugi perusahaan.

Metode Pencatatan persediaan pada CV. KARYA AGUNG LESTARI

CV. KARYA AGUNG LESTARI mencatat persediaan barang dagangannya dengan sitem perpetual sehingga perusahaan dapat mengetahui jumlah persediaan yang ada setiap saat karena catatan, persediannya mampu menyajikan data dari setiap transaksi pemasukan 
maupun pengeluaran barang dagangan secara lengkap dan akurat.

$\underline{\text { Jurnal Pembelian }}$

Pada tanggal 5 Januari 2013, CV. KARYA AGUNG LESTARImembeli obat Analsik sebanyak300unit @Rp.1.200

Persediaan $\quad 360.000$

Kas $\quad 360.000$

Pencatatan pembelian ini dilakukan oleh bagian akuntansi apabila barang yang dipesan telah diterima oleh bagian logistic dan dokumen dasar pencatatannya adalah faktur pembelian.Pencatatan perminttan barang dagang dilakukan oleh kepala logistic berdasarkan dokumen permintaan barang dagang.

Jurnal Penjualan

Pada tanggal 10 Januari 2013, CV. KARYA AGUNG LESTARI menjual obat Analsik sebanyak 200 unit Rp 260.000 (HPP.Rp.234.500)

Kas $\quad 260.000$

Penjualan 260.000

HPP 234.500

Persediaan 234.500

Alasan penggunaan sistem pencatatan perpetual adalah karena banyaknya jenis produk atau jenis barang yang dijual, sehingga memerlukan sistem pencatatan yang selalu dapat memberikan informasi tentang persediaan baik dari jumlah unit, harga perolehan per unit dan total nilai persediaan yang dimiliki.Hal tersebut juga didukung oleh perputaran persediaan yang sangat cepat sehingga dengan adanya informasi yang tersedia dengan cepat dan lengkap memudahkan pihak manajemen dalam mengantisipasi setiap peluang penjualan maupun penurunan penjualan sehingga selalu tersedia untuk mencegah kelebihan maupun kekurangan persediaan.Sehingga kebutuhan pasar yang meningkat pada masa tertentu dapat dipenuhi dan perusahaan dapat terhindar dari penumpukan persediaan pada saat permintaan pasar turun. 
Metode penilaian persediaan berdasarkan PSAK No. 14 (revisi 2012) dalam penetuan nilai sediaan per unit, maka nilainya didasarkan pada prinsip biaya. Nilai sediaan yang ditentukan berdasarkan prinsip biaya disebut dengan metode harga pokok (cost method). CV. KARYA AGUNG LESTARI menggunakan metode penilaian persediaan FIFO, dimana barang yang pertama masuk akan dijual atau digunakan terlebih dahulu sehingga yang tertinggal dalam persediaan akhir adalah yang dibeli atau diproduksi kemudian.

\section{Pembahasan}

Analisis Unsur-unsur Pengendalian Intern Persediaan, sebagai berikut:

a. Lingkungan Pengendalian Persediaan Barang Dagangan

Manajemen CV. KARYA AGUNG LESTARI menganggap bahwa lingkungan pengendalian atas persdiaan barang dagangan itu penting. Lingkungan pengendalian persediaan barang dagangan pada CV. KARYA AGUNG LESTARI akan di analisa dan dievaluasi berdasarkan faktor-faktor yang menyusun lingkungan pengendalian dari perusahaan.

b. Penilaian resiko

Penilaian resiko yang dilakukan oleh manajemen agar penyajian informasi persediaan barang dagangan adalah wajar dan tepat waktu sudah cukup baik.Manajemen telah mengenali dan mempelajari resiko-resiko yang ada, serta membentuk aktivitas-aktivitas pengendalian yang diperlukan untuk menghadapi hal tersebut.

Penetuan resiko persediaan barang dagangan yang ada pada CV. KARYA AGUNG LESTARI dilakukan atas pertimbangan produk farmasi yang masa pakainya sudah lewat, sehingga mengakibatkan berkurangnya penjualan atau menimbulkan kerugian bagi perusahaan, serta pertimbangan atas resiko sanksi hokum dari pemerintah karena penjualan obat-obatan yang dilarang beredar. Hal ini akan mengakibatkan kerugian secara materi dan merusak prestise perusahaan.

c. Aktivitas Pengendalian 
1) Otoritas transaksi

Otorisasi transaksi dan akitivitas dilakukan dengan pembukuan tanda tangan oleh orang yang berwenang pada dokumen untuk transaksi tersebbut, misalnya laporan penerimaan barang dan pengeluaran barang diotorisasi oleh Kabag Logistik.

2) Pemisahan Tugas

CV. KARYA AGUNG LESTARI telah mengadakan pemisahan tugas yang cukup pada setiap transksi atau kegiatan yang berkaitan dengan persediaan barang dagangan. Serta diantaranya adalah pada kegiatan perhitungan fisik persediaan barang dagangan, dilihat bahwa ada pembagian tugas yang jelas, yakni : melaporkan jumlah persediaan barang dagangan gudang oleh kepala bagian logistic, menghitung fisik persediaan, yang terdiri dari Kabag Logistik, Kabag keuangan dan Administrasi, Pimpinan cabang

3) Catatan Akuntansi

CV. KARYA AGUNG LESTARI telah membuat dokumen-dokumen dan catatancatatan yang bertujuan untuk pengawasan persediaan, namun dokumen-dokumen tersebut tidak mempunyai nomor urut tercetak. Tidak adanya nomor urut tercetak ini akan melemahkan pengendalian intern pada perusahaan, karena hal ini dapat menyebabkan karyawan kurang berhati-hati atau kurang bertanggungjawab dalam penggunaan formulir dan bukti transaksi lainnya lebih dari satu kali.

4) Pengendalian Akses

Perlindungan fisik atas persediaan barang dagangan pada perusahaan ini sudah cukup memadai, yakni tersedianya gudang sebagai tempat penyimpanan dan dilengkapi dengan tabung gas untuk menanggulangi bahaya kebakaran, serta dikunci oleh pegawai logistic yang berwenang setelah jam kerja selesai.

5) Pengecekan independen atas pelaksanaan

Perusahaan ini telah melakukan pemisahan fungsi yang berhubungan dengan pengawasan persediaan.Kebijakan perusahaan ini secara tidak langsung menciptakan 
suatu pengecekan yang independen diantara bagian-bagian yang melakukan penjualan, mengeluarkan barang, mengirimkan barang, yang mencatat, dan bagian yang membuat faktur.

\section{d. Informasi dan Komunikasi}

Sistem informasi dan komunikasi yang dilakukan oleh CV. KARYA AGUNG LESTARI sudah cukup baik. Hal ini dapat dilihat dari penyusunan prosedur yang jelas didalam perusahaan, termasuk dalam prosedur pengawasan persediaan barang dagangan yang melibatkan beberapa fungsi terkait, dokumen dan catatan yang diperlukan serta laporan yang dihasilkan dan pencatatan kedalam catatan akuntansi harus didasarkan atas lapaoran sumber yang dilampiri dengan dokumen pendukung yang lengkap yang lebih di otorisasi oleh pihak yang berwenang.

e. Pemantauan

Pemantauan dilakukan dengan membantu manajer untuk mengetahui ketidakefektifan pelaksanaan unsure-unsur pengendalian yang lain. CV. KARYA AGUNG LESTARI melakukan pemantauan persediaan barang dagngan dengan melakukan stok opname setiap bahannya untuk disesuaikan dengan perkembangan permintaan konsumen, serta memperhatikan keluhan-keluhan pelanggan. Evaluasi agar penyimpangan yang ditemukan juga merupakan tanggapan yang baik dan mencerminkan adanya kesadaran akan pentingnya pengendalian yang tertanam dalam diri manajemen. Jadi, secara tertulis aktivitas pemantauan yang dilakukan sudah cukup baik dalam mendukung terciptanya pengendalian intern yang memadai dalam perusahaan.

\section{Analisis Penerapan Akuntansi Persediaan Berdasarkan PSAK No14}

CV. KARYA AGUNG LESTARI menggunakan metode pencatatan persediaan menggunakan sistem perpetual, hal ini memudahkan untuk setiap saat dapat mengetahui posisi persediaan secara keseluruhan untuk dapat mengantisipasi peluang penjualan dan penurunan penjualan, penggunaan metode ini telah sesuai dengan PSAK No.14 sebagai pedoman yang berlaku umum di Indonesia dalam pencatatan persediaan. CV. KARYA AGUNG LESTARI melakukan penilaian persediaan dengan metode FIFO karena perusahaan memiliki jenis persediaan yang cukup banyak. Metode ini akan menghasilkan 
persediaan yang ada digudang adalah persediaan yang terakhir dibeli sehingga terhindar dari keusangan atau tanggal kadaluarsa untuk produk-produk alat kesehatan maupun obat-obatan. Dalam hal ini perusahaan telah sesuai dengan PSAK No.14 dimana barang yang pertama kali dijual adalah barang yang pertama kali masuk, sehingga persediaan yang tertinggal digudang adalah persediaan yang terakhir masuk.

CV. KARYA AGUNG LESTARI telah menyajikan persediaannya dilaba rugi dan dineraca sebagai harta lancar dikelompok pasiva yang disusun perbulan dan laporan tahunan disusun yang menghasilkan laporan keuangan tahunan oleh bagian Akuntansi. Penyajian dalam laporan keuangan, pada PSAK No. 14 diuraikan bahwa laporan keuangan mengungkapkan informasi sebagai berikut:

a. Biaya persediaan yang diakui sebagai beban selama periode berjalan

b. Biaya operasi yang dapat diaplikasikan pada pendapatan.

\section{PENUTUP}

\section{Kesimpulan}

Hasil analisis danevaluasi sistem pengendalian intern dan penerapan akuntansi persediaan barang dagang pada CV. KARYA AGUNG LESTARI tersebut maka penulis mengambil kesimpulan sebagai berikut:

1. Secara keseluruhan sistem pengendalian intern persediaan barang dagang berjalan efektif, dimana manajemen perusahaan sudah menerapkan konsep dan prinsip-prinsip pengendalian intern

2. Metode pencatatan yang dipakai dalam perusahaan CV. KARYA AGUNG LESTARI adalah sistem pencatatan perpetual. Dengan metode perpetual ini dapat dilakukan antisipasi agar tidak terjadinya kekurangan dan kelebihan persediaan. Hal ini telah sesuai dengan PSAK No.14, karena perusahaan selalu mencatat setiap adanya transaksi kedalam akun transaksi dengan demikian setiap saat dapat diketahui jumlah persediaan. 
Metode penilaian yang digunakan adalah FIFO. Sistem FIFO digunakan dimana barang yang pertama masuk pertama keluar hal ini untuk mengantisipasi terjadinya keusangan dan dan habisnya masa tanggal kadaluarsa produk yang dapat menyebabkan kerugian pada pihak perusahaan sehingga menyebabkan laba menurun. Dan metode ini telah sesuai dengan PSAK No.14.

\section{Saran}

Saran yang dapat diberikan penulis CV. KARYA AGUNG LESTARI:

1. Pemisahan fungsi operasi, pencatatan, dan penyimpanan kas sebaiknya dilakukan dengan memdai, dimana kasir hanya berfungsi sebagai penyimpan kas perusahaan dan tidak boleh memiliki akses ke sistem komputer untuk melakukan pencatatan terhadap penjualan barang dagangan.

2. Menciptakan pengendalian intern yang memadai terhadap persediaan perusahaan secara keseluruhan maka sebaiknya manajemen perusahaan membentuk bagian auditor internal agar dapat menyelidiki dan menilai efektivitas pelaksanaan unsur-unsur pengendalian intern persediaan barang yang telah ditetapkan manajemen.

\section{DAFTAR PUSTAKA}

Ackoff, R. L. (1971). Towards a system of systems concepts. Management Science, 17(11), 661-671.

Anastasia, Diana. Setiawan, L. (2010). Sistem Informasi Akuntansi. Penerbit Andy.

Dasaratha, V. Rama-Frederick, L. J. (2008). SISTEM INFORMASI AKUNTANSI. Salemba Empat.

Donald, K. (2002). akuntansi internediate (10 Jilid 1). Erlangga.

Fathansyah. (2015). Basis Data. Revisi Kedua. In Informatika, Bandung.

Hall, A. (1956). D. y FAGEN, R. E. “Definition of System”. General Systems, I, 18-29.

Herry. (2011). Auditing I, Dasar-dasar Pemeriksaan Akuntansi. Kencana.

Horngren. (2009). Akuntansi ( dan H. Charles T. Horngren, Walter T \& Jr (eds.)). Erlangga.

Jogiyanto, H. M. (2005). Analisis \& Desain Sistem Informasi. Yogjakarta: Andi Offset. 
Jusup, A. H. (2001). Dasar-dasar akuntansi jilid II. Sekolah Tinggi Ilmu Ekonomi.

Kadir, A. (2002). Pengenalan Sistem Informasi (Vol. Edisi 2). Yogyakarta: Andi Offset.

Prasetyo, H. N. (2006). Pengembangan Model Persediaan dengan Mempertimbangkan Waktu Kadaluarsa dan Faktor Unit Diskon. Jurnal Ilmiah Teknik Industri 2014. Hal 108-115., 4(3), 08-115.

Rachmad Gesah Mukti prabowo. (2015). Pengembangan sistem.

Sanyoto., G. (2007). Audit Sistem Informasi pendekatan CobIT. Mitra Wacana Media.

STIM, S. \& L. A. (2008). Metodologi Penelitian Untuk Ekonomi Dan Bisnis (Edisi Revi). UPP YKPN.

Suharli, M. (2006). akuntansi untuk bisnis dan barang dagang (G. Ilmu (ed.); pertama).

Sutabri, T. (2012). Analisis sistem informasi. Penerbit Andi.

Warren Carl. S, J. M. R. P. E. F. (2005). Pengantar Akuntansi (21st ed.). Salemba Empat. 